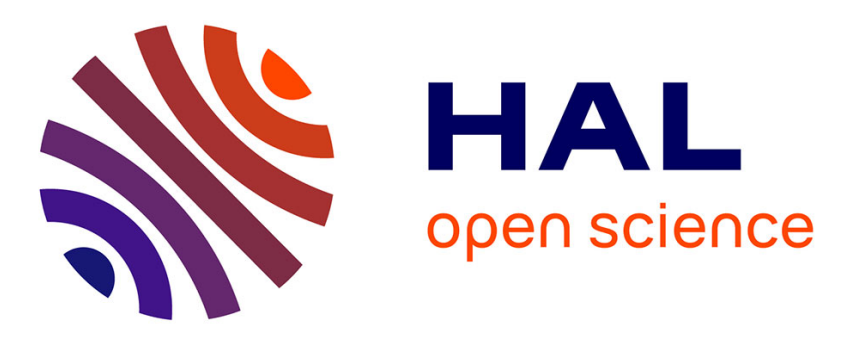

\title{
Service Complexity and Service Productivity in E-Mobility: New Insights from Emergency and Roadway Breakdown Services
}

Aaron W. Baur, Bastian Sander, Robert Kummer, Jörg Von Garrel, Markus Bick

\section{To cite this version:}

Aaron W. Baur, Bastian Sander, Robert Kummer, Jörg Von Garrel, Markus Bick. Service Complexity and Service Productivity in E-Mobility: New Insights from Emergency and Roadway Breakdown Services. 16th Conference on e-Business, e-Services and e-Society (I3E), Nov 2017, Delhi, India. pp.497-513, 10.1007/978-3-319-68557-1_44 . hal-01768526

\author{
HAL Id: hal-01768526 \\ https://hal.inria.fr/hal-01768526
}

Submitted on 17 Apr 2018

HAL is a multi-disciplinary open access archive for the deposit and dissemination of scientific research documents, whether they are published or not. The documents may come from teaching and research institutions in France or abroad, or from public or private research centers.
L'archive ouverte pluridisciplinaire HAL, est destinée au dépôt et à la diffusion de documents scientifiques de niveau recherche, publiés ou non, émanant des établissements d'enseignement et de recherche français ou étrangers, des laboratoires publics ou privés. 


\title{
Service Complexity and Service Productivity in E- Mobility: New Insights from Emergency and Roadway Breakdown Services
}

\author{
Aaron W. Baur ${ }^{1}$, Bastian Sander ${ }^{2}$, Robert Kummer ${ }^{2}$, Jörg von Garrel ${ }^{3}$, and Markus \\ Bick $^{1}$ \\ ${ }^{1}$ ESCP Europe Business School Berlin, Berlin, Germany \\ abaur@escpeurope.eu \\ ${ }^{2}$ Fraunhofer Institute for Factory Operation and Automation IFF \\ Magdeburg, Germany \\ ${ }^{3}$ SRH Fernhochschule - The Mobile University, Riedlingen, Germany
}

\begin{abstract}
The introduction and wide-spread adaptation of e-mobility influences emergency and roadway breakdown service firms. Service complexity and service productivity are important constructs to measure and monitor where the industry is headed and where firms need to quickly adapt.

The purpose of this paper is to investigate effects on service complexity and service productivity of emergency and roadway breakdown services on the back of a growing market penetration of electric vehicles in industrialized countries. The study is grounded on expert interviews and a quantitative analysis of 325 questionnaires that have been distributed among roadside assistant service providers in Germany. It reveals the increasing complexity of an important service industry that had only been studied scarcely in the past. With its large-scale quantitative design, it adds significantly to the body of knowledge available and can be the basis for further advanced research in other geographical settings. The research supports practitioners in the field of roadside assistant services in rethinking their service offering and the handling of increasingly heterogeneous propulsion technologies such as electric drives. In order to keep the service productivity high and the complexity low, assistance systems and targeted qualification and training concepts for the roadway personnel have to be developed and rolled out.

The research setting is focused on the German market, but links are provided to apply the study design to other countries and further investigate respective market singularities.
\end{abstract}

Keywords: E-Mobility, Services, Service Complexity, Service Productivity

\section{$1 \quad$ Introduction and Background}

Individual mobility is still the prime way of transportation for the majority of people in the Western world. For instance, more than $80 \%$ of transport performance in Germany, measured in passenger-kilometers, is delivered through cars and motorbikes [1]. Although many innovations have been introduced, such as the antilock braking 
system, lane assistance or start/stop systems, the use of combustions engines as the primary way of propulsion has remained almost untouched. This continuity of technology ensured a quick emergency response and optimized processes in case of an accident or roadway breakdown.

However, negative news about the climate change and the harmful effects of the oxides of nitrogen and other constituents of exhaust fumes call for action. The political will for a comprehensive introduction of innovative technology and mobility concepts exists in some areas of the world. Pending discussions are on to stop registration of cars with combustion engines within the next decade (e.g., Netherlands and Norway 2025, Germany, India, and California 2030) [2]. E-mobility can be regarded the prime way to reduce local exhaust fumes. Hence, it is now a priority in many industrialized countries globally.

The higher number of hybrid or fully electrical driven vehicles (EVs) on the roads also expectedly increases the likelihood of road accidents and breakdowns which involve electric vehicles. To deliver users of electric vehicles emergency and breakdown services of high quality and timeliness, new concepts and services have to be developed, operationalized and tested that enable effective and secure - but also productive - handling of such situations. The main actors have to be comprehensively sensitized and educated of how to handle electric vehicles after non-planned situations such as breakdowns or accidents.

Thus, we want to shed light with this research on the effects of service complexity and service productivity important roadside assistance firms report, on the back of a growing market penetration of electric vehicles.

The remainder of our paper is structured as follows: section two introduces the theoretical background and framework of peculiarities of electric vehicles and how they affect service complexity and service productivity. Nine hypotheses are developed based on analyzed literature and interviews with experts in the field. Section three explains the research method applied including data gathering and data analysis. In section four, we analyze the data and discuss the results, before we conclude the paper with implications, limitations, and areas of future research in section five.

\section{Theoretical Framework and Hypotheses Development}

Our research framework is built on the concepts of service productivity and service complexity in the context of e-mobility.

\subsection{Characteristics of Electric Vehicles in Emergency Service Contexts}

In this paper, we follow the definition of the German government that defines electric vehicles as passenger cars, light-duty commercial vehicles, motorbikes and micro cars which use electricity as the primary means of fuel [3]. In detail, these are so-called battery electric vehicles (BEV), range-extended electric vehicles (REEV) and plug-in hybrid electric vehicles (PHEV). All of them use a high-voltage (HV) system with up to 1,000 Volts (alternating current, AC) or 1,500 Volts (direct current, DC). If they 
flow through the human body, these voltages can lead to apnea, ventricular fibrillation or death. Although the OEMs have developed various safety features that shut down or isolate the critical components after an accident, residual risks remain. This causes serious implications for emergency rescue or roadside assistance personnel who need to help drivers of EVs. In order to safely deliver the respective services on an EV, the German DEKRA (the European market leader specialized in the inspection of motor vehicles and other technical systems) recommends the use of additional safety equipment for emergency personnel, such as electrical protection gloves, safety helmets with full visors and voltage testers. Because of these new technical developments and a lack of experience, emergency and roadside assistance firms express uncertainty of how to handle electric vehicles in breakdown or accident situations. Additionally, the incident of an EV of the US National Highway Traffic Safety Administration (NHTSA) that started burning three weeks after a conducted crash test, damaging three additional vehicles and a warehouse, increases this uncertainty [4].

The missing standardization across manufacturers is another issue. For instance, some vehicles are clearly marked as electric, others are not; safety cards that show the HV components are included in some vehicles, but not in others; or some vehicles can be towed, others have to be picked up. Finally, there are technological peculiarities of EVs that in the case of a non-planned event cause risks to safety personnel that cannot be completely controlled, no matter how advanced the safety and cut off provisions are. For example, the electro-chemical accumulators cannot be completely turned off and contain health hazardous substances or reaction products [5], which pose a risk to personnel especially when accidents cause mechanical deformations on the high voltage components. Hence, the service firms perceive a lack of process stability when it comes to electric vehicles in general, but in particular when handling non-planned operational situations.

\subsection{Excellence of Service}

To ensure the success of the politically enforced electric mobility, the quality, safety and productivity of rescue services must be ensured through efficient work processes and a profound qualification of service providers and (end) users of electric vehicles. The concepts of excellence of services, service complexity and service productivity and can be used to characterize these roadside services (cf. [6]).

Excellence of service is made up of the service provider which is based on the factors service productivity and service complexity, and the service consumer, based on service quality (Fig. 1). 


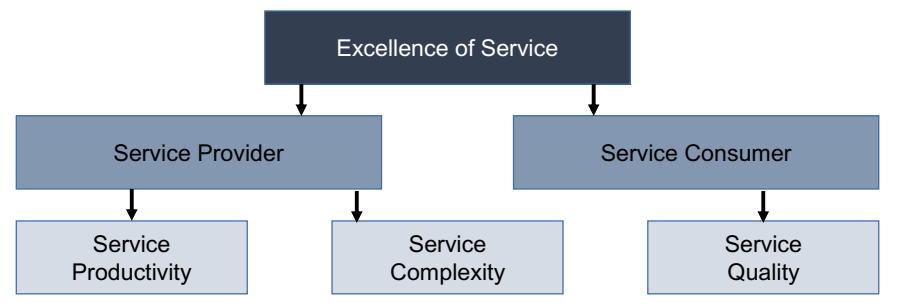

Fig. 1. Breakdown of excellence of services (Source: own visualization)

Service productivity. Productivity describes the ratio of output to input [7]. When measuring productivity of services, the integration of the external factor, i.e., the customer, and its immateriality pose the greatest difficulties [8]. To just transfer the classical understanding of productivity into an interactive and integrative service process will not pay off [9]. Authors therefore focus on the efficiency of external processes [10], and the effectiveness of delivering the service (customer satisfaction, customer benefit and economic success). Measures to design service productivity thus entail aspects of efficiency, effectiveness, and their possible interdependencies [6, 11].

In this paper, we follow the model of [12] and define service productivity as a function of (1) how effectively input resources into the service (production) process are transformed to outputs in the form of services (internal efficiency), (2) how well the quality of the service process and its outcome is perceived (external efficiency or effectiveness) and (3) how effectively the capacity of the service process is utilized (capacity efficiency).

For instance, the construct of service productivity is comprised of efficiency and effectiveness, the effectiveness being defined as the external efficiency while the efficiency is comprised of internal and capacity efficiency (see Fig. 2). The effective and efficient delivery of services is characterized by (1) the efficient input of production resources and the ability of the service provider to integrate its customers as value-adding actors into the service delivery process (internal efficiency), (2) the handling of demand (capacity efficiency) and (3) the resulting customer benefit and the degree of perceived service quality that a firm can generate with a pre-set input of resources (external efficiency) [13].

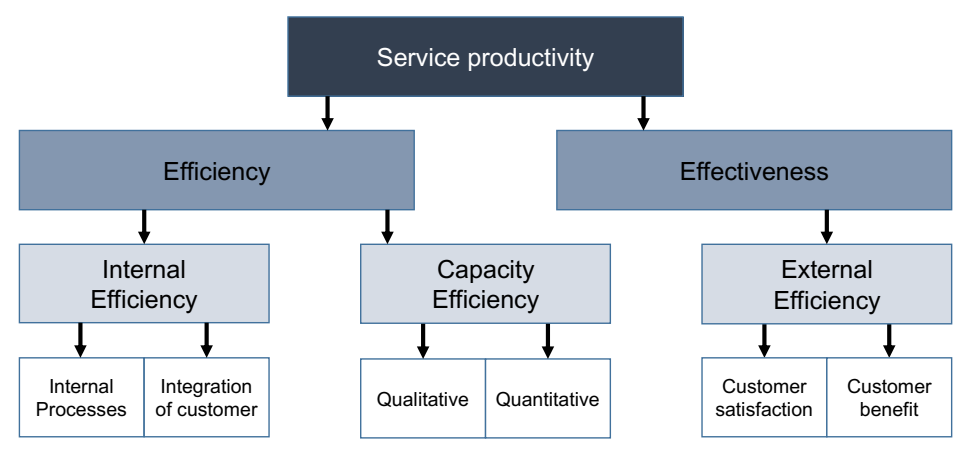

Fig. 2. Breakdown of service productivity (Source: based on [13]) 


\subsection{Hypotheses Development}

Understanding service productivity as the combined effect of how well a service provider manages the cost efficiency of its service production resources [14], its processes (internal efficiency) and the perceived quality of its services (external

efficiency), leads to several hypotheses.

Employee Base of the Firm. In order to be able to deliver roadside assistance services, the providers have to hold a certain number of employees available. Of them, some are administrative, but the majority naturally ought to be roadside assistants that actually deliver the service to customers on the road. Larger firms can normally afford to purchase more modern technical equipment and potentially provide a more thorough qualification to their employees. Especially factors regarding the capacity efficiency should be positively influenced. We therefore hypothesize:

Hypothesis $1 a$ There is an interrelation between service productivity and number of employees within the firm.

Hypothesis $1 b$ There is an interrelation between service productivity and number of roadside assistants within the firm.

Qualification Base of Employees. As discussed before, for workers to deliver roadside services to electric vehicles, the peculiarities of these new types of vehicles have to be known and trained. One of the most-common and most-suited qualification is the so-called BGI86861 certificate, which gives the non-electric basics in handling EVs, e.g., switching tires, doing an oil exchange, or any other mechanical task.

Hypothesis 2 The BGI 8686 certificate increases the likelihood of whether the ser vice provider has already delivered roadside assistance to EVs.

Similarly, employees that enjoy a higher degree of training in the context of EVs may be suited to judge the higher level of service complexity and service productivity that electric vehicles cause.

Hypothesis $3 a$ Respondents who have the BGI 8686 qualification judge the service complexity of EVs higher than those that do not have it.

Hypothesis $3 b$ Respondents who have the BGI 8686 qualification judge the service productivity of EVs higher than those that do not have it.

Level of Experience. A higher degree of experience with the emergency and breakdown service for electric vehicles may change the way employees judge service complexity and service productivity. We hypothesize:

Hypothesis $4 a$ Firms which have already delivered roadside assistance to EVs judge service complexity of EVs higher than those firms that did not deliver such services.

Hypothesis $4 b$ Firms which have already delivered roadside assistance to EVs judge service productivity of EVs higher than those firms that did not deliver such services.

1 The certificate BGI/GUV-I 8686 is issued by the "Deutsche Gesetzliche Unfallversicherung", i.e., the German Casualty Insurance. It has been renamed to "DGUV Information 200-005 - Qualifizierung für Arbeiten an Fahrzeugen mit Hochvoltsystemen" (qualification to work with vehicles with high-voltage systems). 
Current Level of Action. Many firms have realized the necessity to adapt to an increasing installed base of electric vehicles and have started to get ready for the change. Consequently, we hypothesize:

Hypothesis $5 a$ There is a difference between the judgement of service complexity of roadside assistance for EVs of firms which have implemented certain measures regarding e-mobility and those that did not implement these measures.

Hypothesis $5 b$ There is a difference between the judgement of service productivity of roadside assistance for EVs of firms which have implemented certain measures regarding e-mobility and those that did not implement these measures. These hypotheses will be tested below, bringing the characteristics of electric vehicles and the concepts of service productivity and service complexity together.

\section{$3 \quad$ Research Method}

In order to shed light on the service phenomenon of roadside assistance services with electric vehicles, the research has been conducted based on a qualitative sample and statistical calculations.

\subsection{Research Setup}

A multi-step approach has been taken to analyze how electric vehicles today already impact the services of roadway breakdown firms.

In a first step, an approximation on the construct of excellence of a service was conducted based on a theory-driven conceptualization (see section 2). Through further research and analyses, the three factors service productivity, service complexity and service quality could be operationalized. An initial interview guideline was set up and used as a basis for conversations and interviews with experts of two large roadside assistance clubs. The content analysis of these interviews then lead to a first formulation of items that enabled the measurement of the respective factors and thus the excellence of a roadside service.

In a second step, to measure the abovementioned service productivity, the operationalized and validated item battery of [13] has been used. Analogous to that battery, a total of 25 items were formulated that were adapted to the processes, work organization and the industry language of roadside breakdown services in terms of comprehensibility and clearness. Items that were less relevant were partially reformulated or replaced by more exact ones.

\subsection{Data Gathering and Analysis}

Following a project-internal test of the questionnaire (clearness, structure and logic of questions, time needed to complete it), a pre-test was conducted at IFBA, the leading European professional towing and rescue trade fair, held in Kassel (Germany) ${ }^{2}$. Over-

2 http://www.ifba.eu/index.html 
all, 48 roadside assistants were questioned. Through discussions with some of the questioned individuals, further important bits of information could be gathered. Based on the results, the questionnaire was updated and optimized/validated using factor analysis. The update has again been tested internally to then issue the final version, which was comprised of 4 areas with 16 item blocks, containing a total of 91 items (e.g., what services are offered, experience with electric vehicles and judgements of the complexity and productivity of the services offered).

The paper-based questionnaires were then sent out across Germany to the members of two large automobile clubs/assistance services. The survey method has been deemed most appropriate for gaining a high, representative number of data across the whole country which consists of different hierarchy and qualification levels of the emergency service companies $[15,16]$. An overview of the approach is given in Fig. 3.

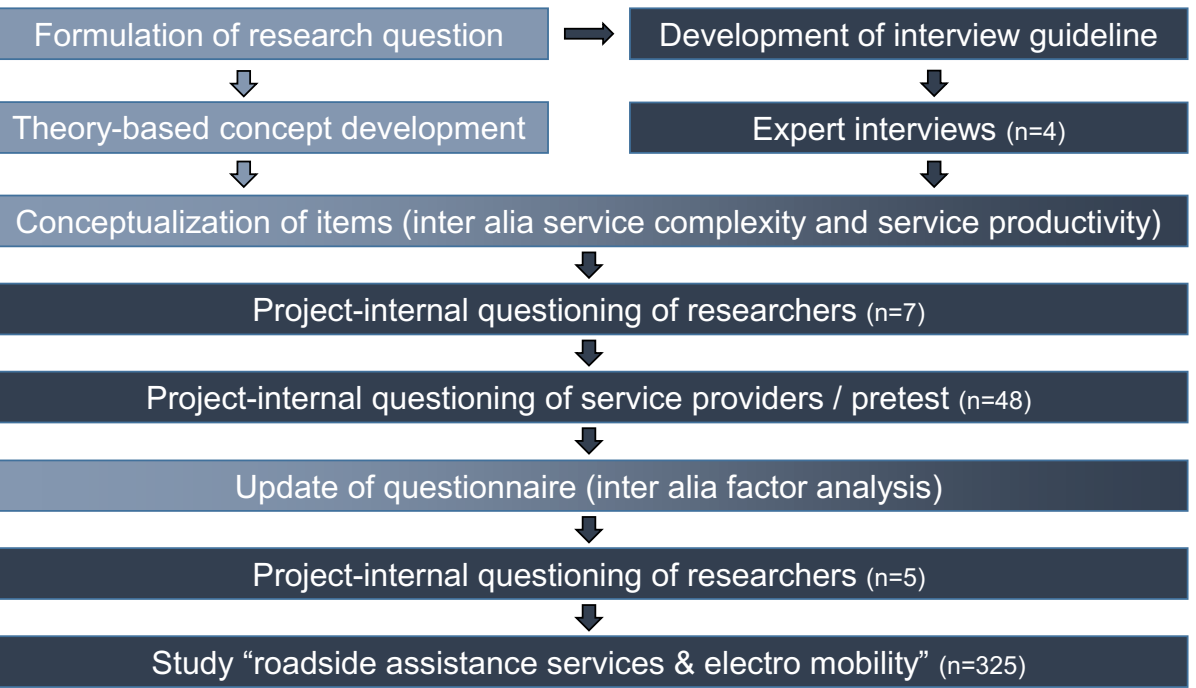

Fig. 3. Methodical overview of quantitative research approach (Source: own visualization)

Of the 325 collected surveys, 314 could be used for data analysis (11 surveys were taken out of the sample, as they were from the same firm and had identical answers, leaving the impression they were all filled in by the same person). The data were recorded and coded (primarily binary) in Microsoft Excel to be analyzed in IBM SPSS Statistics v24 [17]. Multiple imputations were then calculated with this software to replace missing data and to minimize the effects of non-response bias on certain questions.

With the final data set, we conducted a factor analysis (VariMax rotation). Based on the Eigenwerte, we kept three factors and tested the internal consistency afterwards with a reliability analysis. Service productivity reached a Cronbach's Alpha of 0.721, displaying a fair reliability. Service complexity, on the other hand, reached an even slightly higher internal consistency with an Alpha of 0.740 . 


\section{$4 \quad$ Results and Discussion}

In this section, the results and implications of the aforementioned research process are presented and discussed.

\subsection{Descriptive Analysis}

In order to get a better view of the sample, we analyzed several important descriptive statistics. The number of employees averaged 13, with a minimum of 1 and a maximum of 220 , thereof $42 \%$ were roadside assistants.

As a proxy for job experience, we asked about the number of years the person has been employed at the current company and which position he has got. The distribution and ratio of executives/owners to employees points towards a good quality of the sample (Fig. 4).
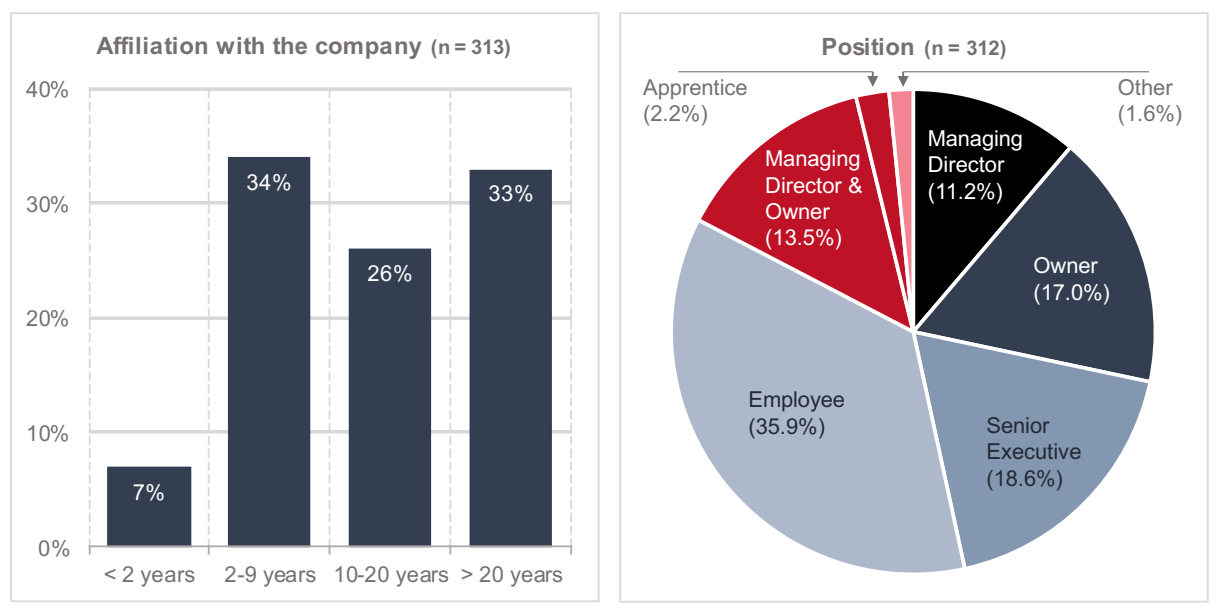

Fig. 4. Duration of company affiliation and current position

As for the qualification of the respondents, the questionnaire asked for the professional background and additional certificates proofing knowledge of how to handle roadside accidents and the recovery of electric vehicles. More than $61 \%$ of respondents had the qualification "towing and recovery professional", and $47 \%$ had an apprenticeship as a motor mechanic. 30\% have acquired the "BGI 8686 certificate for highvoltage vehicles", which is important in our research context.

\subsection{Hypothesis Testing and Discussion}

In H1a, we hypothesized the number of employees having an effect on the service productivity. According to Spearman's rank correlation coefficient (rho, $\rho$ ) of 0.06 and a p-value of 0.307 (two-tailed), respectively, we cannot refuse the null- 
hypothesis. The number of employees neither influences the internal or external efficiency, nor the capacity efficiency.

In part $\mathrm{b}$ of Hypothesis 1 , the number of roadside assistants within the firm had been checked. With rho $=0.106$ and the $p$-value $=0.069^{* 3}$ (two-tailed), we can refuse the null-hypothesis and find a significant, positive effect on the 10-percent-level. Looked on the different statements separately, significant relationships can be noticed in the following efficiencies (framed in red, Table 1):

Table 1. Three pillars of service productivity with rho and p-values

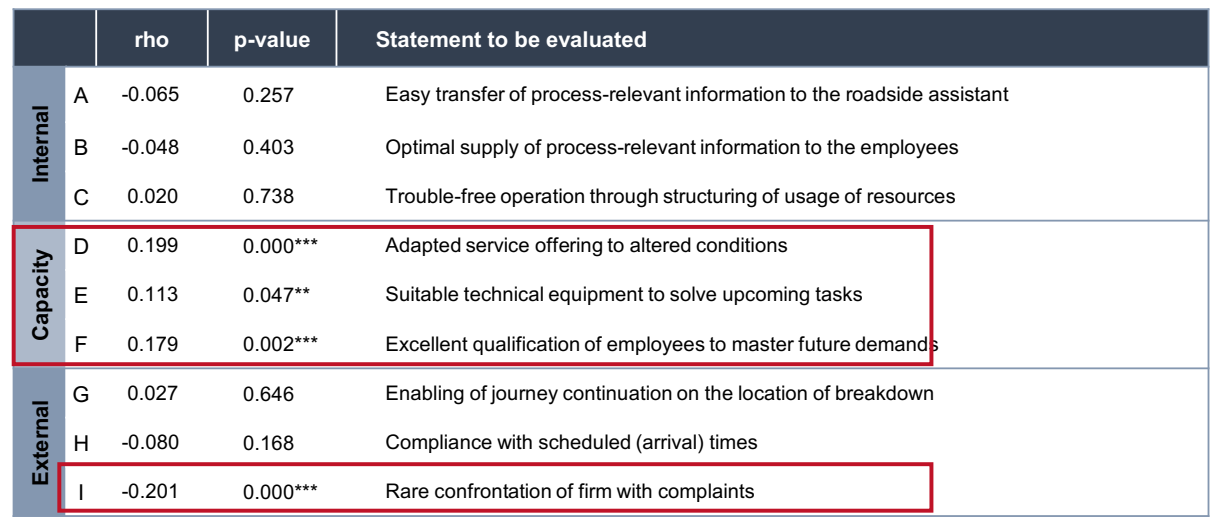

The service productivity hence increases especially with capacity factors. It decreases if the number of complaints decreases.

Service productivity is not related to the overall number of employees in the service firms. However, there is a significant effect of the number of roadside assistants delivering the service. Especially the capacity efficiency is higher, resulting from greater financial possibilities of larger firms, which increases service offerings, equipment and qualification of employees. For smaller players in the field, this is bad news: With an increasing number of propulsion technologies on the market, they may not be able to keep pace with developments, leading to lower service productivity of their roadside staff and to potentially lower profits in the mid- to long-term.

With $\mathrm{H} 2$, it has been tested if the BGI 8686 certificate increases the likelihood of whether the service provider has already delivered roadside assistance to EVs. With a Chi-Quadrat (Pearson) of $\mathrm{p}=0.000 * * *$, value $=38.963$ and after an exact Fisher test (one-tailed $0.000^{* * *}$ ), the null hypothesis can be refused.

Hence, certificates/qualifications like the BGI 8686 are decisive whether roadside assistance is delivered or not (see Table 2).

\footnotetext{
${ }^{3}$ For the remainder of this paper, the level of significance is represented with asterisks: $*=10 \%, * *=5 \%, * * *=1 \%$
} 
Table 2. Number of respondents with and without BGI 8686 certificate

\begin{tabular}{|c|c|c|c|c|}
\hline & & \multicolumn{3}{|c|}{ Roadside breakdown services for electric vehicles } \\
\hline : & & No & Yes & Total \\
\hline ב & No & 109 & 109 & 218 \\
\hline שِّ & Yes & 12 & 83 & 95 \\
\hline वีّ & Total & 121 & 192 & 313 \\
\hline
\end{tabular}

Companies with qualified employees are therefore more likely to offer services to electric vehicle than companies with less qualified staff.

In $\mathrm{H} 3 \mathrm{a}$, we tested whether respondents that have the BGI 8686 qualification judge the service complexity of EVs higher than those that do not have it. The result of a Mann-Whitney-U-Test ( $\mathrm{p}$-value $=0.786$ ) leads to a non-rejection of the null hypothesis, i.e., the qualification BGI 8686 of respondents does not increase the judgment of service complexity. The more heterogeneous approach, a higher variety of work tasks, and the demands to meet the more sophisticated technology are evaluated without differences. A significant difference can only be observed in regard to judgement of the employee qualifications (employee complexity, see Table 3). Here, BGI 8686 qualified workers appreciate that a higher qualification is needed.

Table 3. Analysis of different statements of $\mathrm{H} 3 \mathrm{a}$

\begin{tabular}{|c|c|l|}
\hline & p-value & Statement to be evaluated \\
\hline A & 0.502 & More heterogenous approach/procedure \\
B & 0.554 & Higher variety of work tasks \\
C & 0.350 & More sophisticated technology \\
\hline D & $0.038^{* *}$ & Higher qualification of employees \\
\hline
\end{tabular}

In the second part of this hypothesis, H3b, we checked whether the BGI 8686 qualification increases the judgment of service productivity. The Mann-Whitney-U-Test showed a p-value of $0.002 * * *$, the hypothesis can be accepted. The qualification BGI 8686 of respondents increases the judgment of service productivity.

When looking at the different statements separately, two of three capacity efficiency factors show significant p-values (Table 4). Firms of respondents which have got the BGI 8686 qualification have got a higher service productivity, especially regarding the service offering adaptation and the employee qualification. 
Table 4. Analysis of different statements of $\mathrm{H} 3 \mathrm{~b}$

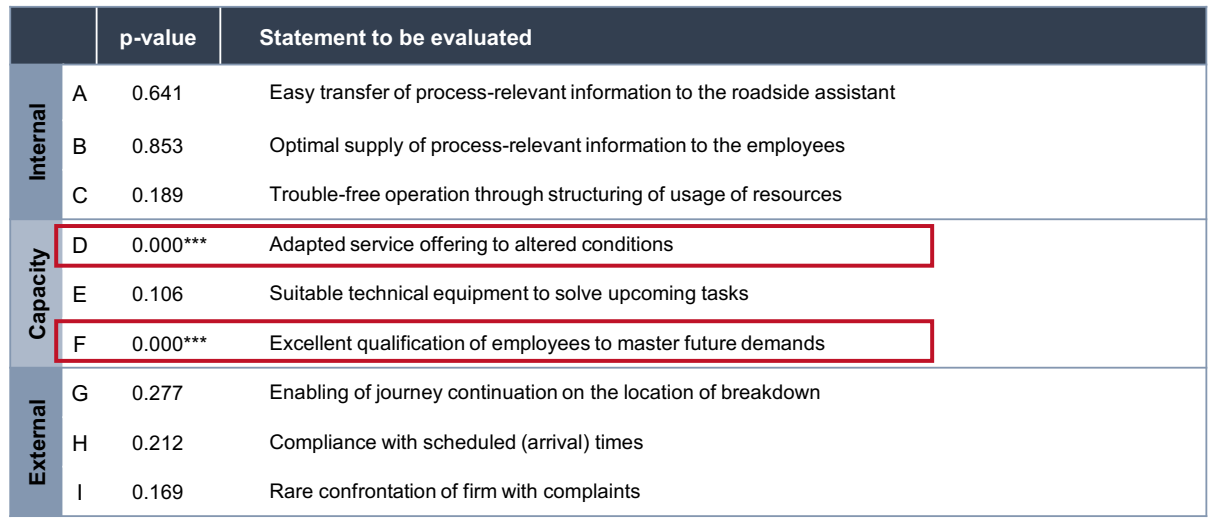

In terms of experience, we tested in $\mathrm{H} 4 \mathrm{a}$ whether personnel of firms with $\mathrm{EV}$ roadside service experience judge service complexity higher to those that do not have experience. As can be seen in Fig. 5, service providers, which have already delivery roadside breakdown services to EVs, judge these services as being more complex in regard to qualification and technology when compared to conventional vehicles. The differences are not significant, though.

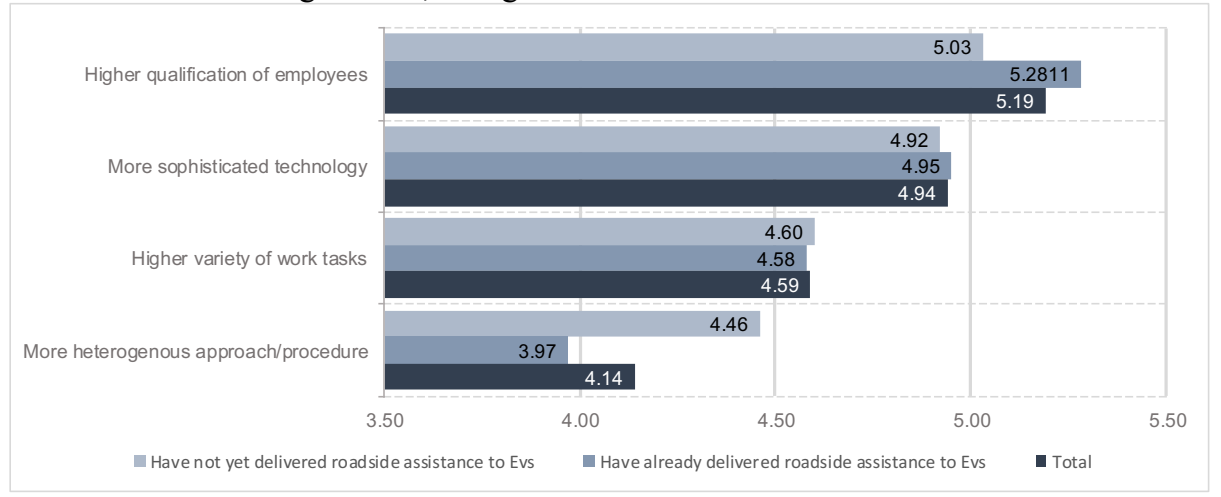

Fig. 5. Judgement of service complexity

The Mann-Whitney-U-Test resulted in a p-value of 0.214 , hence the null hypothesis cannot be rejected. The evaluation of service complexity seems not to be related to the level of experience with services for electric vehicles. Only one statement lead to a significant value, i.e., the complexity regarding the approach/procedure is seen higher by staff with experience than by those without (Table 5). 
Table 5. Analysis of different statements of $\mathrm{H} 4 \mathrm{a}$

\begin{tabular}{|c|c|l|}
\hline \multicolumn{1}{|l|}{} & $\mathbf{p}$-value & Statement to be evaluated \\
\hline A & $0.016^{\star \star}$ & More heterogenous approach/procedure \\
\hline B & 0.772 & Higher variety of work tasks \\
C & 0.947 & More sophisticated technology \\
D & 0.116 & Higher qualification of employees \\
\hline
\end{tabular}

On the other hand, the questioned items in regard to service productivity $(\mathrm{H} 4 \mathrm{~b})$ lead to a p-value of $0.02 * *$, hence the null hypothesis can be rejected. Service productivity depends on the experience of services with EVs, this is visible especially in the items that make up the capacity factor (Fig. 2). Firms with EV experience show a higher service productivity judgement.

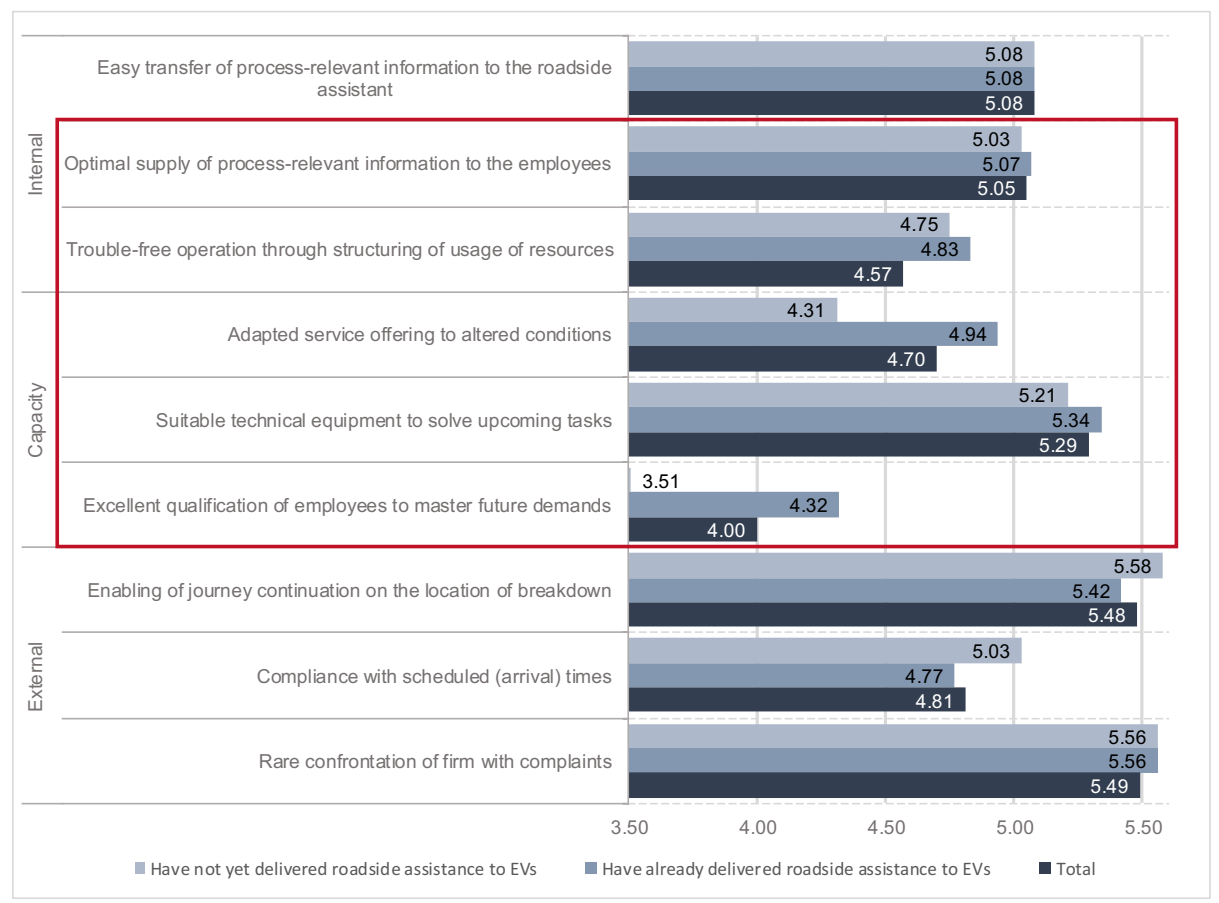

Fig. 2. Analysis of different statements of $\mathrm{H} 4 \mathrm{~b}$

The absolute values for the different statements are confirmed by the Mann-WhitneyU-Test (Table 6): 
Table 6. Analysis of different statements of $\mathrm{H} 4 \mathrm{~b}$

\begin{tabular}{|c|c|c|c|}
\hline & & p-value & Statement to be evaluated \\
\hline 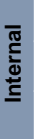 & $\begin{array}{l}\text { A } \\
\text { B } \\
\text { C }\end{array}$ & $\begin{array}{l}0.892 \\
0.430 \\
0.177\end{array}$ & $\begin{array}{l}\text { Easy transfer of process-relevant information to the roadside assistant } \\
\text { Optimal supply of process-relevant information to the employees } \\
\text { Trouble-free operation through structuring of usage of resources }\end{array}$ \\
\hline 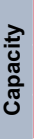 & $\begin{array}{l}\text { D } \\
\text { E } \\
\end{array}$ & $\begin{array}{l}0.000^{\star \star *} \\
0.025 \\
0.000^{\star \star *}\end{array}$ & $\begin{array}{l}\text { Adapted service offering to altered conditions } \\
\text { Suitable technical equipment to solve upcoming tasks } \\
\text { Excellent qualification of employees to master future demands }\end{array}$ \\
\hline 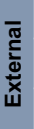 & $\begin{array}{l}\text { G } \\
\mathrm{H} \\
\mathrm{I}\end{array}$ & $\begin{array}{l}0.068 \\
0.102 \\
0.928\end{array}$ & $\begin{array}{l}\text { Enabling of journey continuation on the location of breakdown } \\
\text { Compliance with scheduled (arrival) times } \\
\text { Rare confrontation of firm with complaints }\end{array}$ \\
\hline
\end{tabular}

The comparison of both groups (experience and no experience) validates these significant differences. The whole concept of service productivity as well as the capacity efficiency deliver significant $\mathrm{p}$-values (Table 7).

Table 7. Comparison of means of two different groups (H4b)

\begin{tabular}{|c|c|c|c|}
\hline & Mean if no services for EVs & Mean if services for EVs & p-value (Mann-Whitney-U-test) \\
\hline $\begin{array}{l}\text { Self } \\
\text { Evaluation }\end{array}$ & $\begin{array}{l}4.314 \\
N=121\end{array}$ & $\begin{array}{l}4.396 \\
N=192\end{array}$ & 0.564 \\
\hline $\begin{array}{l}\text { Service } \\
\text { Productivity }\end{array}$ & $\begin{array}{l}4.847 \\
N=112\end{array}$ & $\begin{array}{l}5.028 \\
N=182\end{array}$ & $0.002^{* * *}$ \\
\hline $\begin{array}{l}\text { Internal } \\
\text { Efficiency }\end{array}$ & $\begin{array}{l}4.814 \\
N=120\end{array}$ & $\begin{array}{l}4.962 \\
N=191\end{array}$ & $0.082^{*}$ \\
\hline $\begin{array}{l}\text { Capacity } \\
\text { Efficiency }\end{array}$ & $\begin{array}{l}4.351 \\
N=115\end{array}$ & $\begin{array}{l}4.888 \\
N=184\end{array}$ & $0.000^{* * *}$ \\
\hline $\begin{array}{l}\text { External } \\
\text { Efficiency }\end{array}$ & $\begin{array}{l}5.336 \\
N=118\end{array}$ & $\begin{array}{l}5.225 \\
N=188\end{array}$ & $0.087^{*}$ \\
\hline
\end{tabular}

Finally, we asked the professionals regarding the complexity and productivity in the light of whether the firms have implemented certain measures related to e-mobility. Regarding hypotheses H5a and H5b, the Kruskal-Wallis-Test for service complexity did not deliver significant results, i.e., the null hypothesis cannot be rejected. The measures have no influence on the evaluation of service complexity (Table 8). 
Table 8. P-values of service complexity on different measures (H5a)

\begin{tabular}{|l|c|}
\hline \multicolumn{1}{|c|}{ Measures } & \multicolumn{1}{|c|}{ p-values of service complexity } \\
\hline Training of employees & 0.841 \\
\hline Flexibilization of workforce & 0.105 \\
\hline Extension of vehicle fleet & 0.137 \\
\hline Purchase of technical equipment & 0.317 \\
\hline Technical adaptation of vehicle fleet & 0.729 \\
\hline
\end{tabular}

On the other hand, the Kruskal-Wallis-Test for service productivity revealed significant differences between the groups that have taken the measures, have planned to do so or are not planning to take them (besides the measure "flexibilization of workforce $\left.^{4,}\right)$. Therefore, the null hypothesis can be rejected.

When looking at the different efficiencies of service productivity, the significant differences are - again - mainly in the capacity efficiency (Table 9).

Table 9. Comparison of means of two different groups (H5b)

\begin{tabular}{|l|c|}
\hline \multicolumn{1}{|c|}{ Measures } & p-values of service complexity \\
\hline Training of employees & $0.000^{\star \star \star}$ \\
\hline Flexibilization of workforce & 0.278 \\
\hline Extension of vehicle fleet & $0.005^{\star \star \star}$ \\
\hline Purchase of technical equipment & $0.000^{\star \star \star}$ \\
\hline Technical adaptation of vehicle fleet & $0.000^{\star \star \star}$ \\
\hline
\end{tabular}

To summarize the empirical findings, we got a mixed picture of accepted and rejected hypotheses based on the underlying data set. Some hypothesized assumptions could not be confirmed, but overall, our analyses confirmed the results of our factor and subsequent reliability analysis.

Table 10 shows the correlation of constructs regarding service productivity.

4 This exception may be due to the respondents' improper understanding of the meaning of this item. 
Table 10. Correlation of constructs (service productivity)

\begin{tabular}{|c|c|c|c|c|c|}
\hline & $\begin{array}{c}\text { Self } \\
\text { Evaluation (a) }\end{array}$ & $\begin{array}{c}\text { Service } \\
\text { Productivity }{ }^{(b)}\end{array}$ & $\begin{array}{l}\text { Internal } \\
\text { Efficiency }\end{array}$ & $\begin{array}{l}\text { Capacity } \\
\text { Efficiency }\end{array}$ & $\begin{array}{l}\text { External } \\
\text { Efficiency }\end{array}$ \\
\hline $\begin{array}{l}\text { Self } \\
\text { Evaluation }\end{array}$ & $\begin{array}{c}1 \\
\mathrm{~N}=313\end{array}$ & $\begin{array}{l}0,269^{* * *} \\
\mathrm{~N}=254\end{array}$ & $\begin{array}{c}0,287^{* * *} \\
\mathrm{~N}=311\end{array}$ & $\begin{array}{c}0,200^{* * *} \\
N=299\end{array}$ & $\begin{array}{c}0,154^{* * *} \\
N=306\end{array}$ \\
\hline $\begin{array}{l}\text { Service } \\
\text { Productivity }\end{array}$ & & $\begin{array}{c}1 \\
\mathrm{~N}=294\end{array}$ & $\begin{array}{c}0,766^{* * *} \\
N=294\end{array}$ & $\begin{array}{c}0,752^{* * *} \\
\mathrm{~N}=294\end{array}$ & $\begin{array}{c}0,643^{* * *} \\
\mathrm{~N}=294\end{array}$ \\
\hline $\begin{array}{l}\text { Internal } \\
\text { Efficiency }\end{array}$ & & & $\begin{array}{c}1 \\
\mathrm{~N}=311\end{array}$ & $\begin{array}{l}0,381 * * * \\
\mathrm{~N}=298\end{array}$ & $\begin{array}{l}0,442^{* * *} \\
\mathrm{~N}=304\end{array}$ \\
\hline $\begin{array}{l}\text { Capacity } \\
\text { Efficiency }\end{array}$ & & & & $\begin{array}{c}1 \\
\mathrm{~N}=299\end{array}$ & $\begin{array}{c}0,172^{* * *} \\
\mathrm{~N}=295\end{array}$ \\
\hline $\begin{array}{l}\text { External } \\
\text { Efficiency }\end{array}$ & & & & & $\begin{array}{c}1 \\
\mathrm{~N}=306\end{array}$ \\
\hline $\begin{array}{l}\text { a) Self evaluatit } \\
\text { b) Mean of inte }\end{array}$ & $\begin{array}{l}\text { ice productivity. } \\
\text { nal and capacity }\end{array}$ & & & & \\
\hline
\end{tabular}

Service complexity measured with 4 items resulted in a Cronbach's Alpha $\alpha=0.740$. As frequently mentioned above, the data reveals again that service productivity is mainly defined by capacity and internal aspects. Looking at the internal consistency, it resulted in 9 items with a Cronbach's Alpha $\alpha$ of 0.721 .

\section{Conclusion}

\subsection{Implications and Recommendations}

It was our research aim to investigate how roadside traffic service providers experience service complexity and service productivity [18] on the back of an increasing installation base of electric vehicles.

As detailed above, the higher number of electric vehicles on the roads calls for new or - at the least - an adaption of roadside assistance and breakdown services. By now, most providers have realized that. More qualifications and trainings for employees and the acquisition and use of more advanced technical equipment are measures that have been partially taken by the players in the field.

The contribution of our research is twofold: In the scientific community, there is very little service research in the context of roadside assistants and e-mobility. The research presented here can help to stimulate discussion in order to ignite further necessary investigation. Service literature states that an optimal balance between perceived service quality and productivity has to be maintained by the service provider's inputs in the process, in order to guarantee excellent performances [19].

From a managerial point of view, roadside assistant providers get valuable insights on how to adapt to future disruptive changes in technology, which result in fluctuating demand for roadside assistance services. However, through an ongoing adaption process, service providers can find and maintain an optimal balance between perceived quality and internal efficiency. 
Service providers must learn from their customers how to meet their demands and adequately adjust to their value systems. By doing so, service productivity is improved over time.

Only if the quality and quantity/availability of e-mobility roadside assistance services keeps up the high standards they used to have with combustion engines, will the e-mobility be adapted quickly and successfully.

\subsection{Limitations and Future Research}

The study also contains certain limitations which we would like to address. First, the research has been conducted in the German roadside assistance market only. Questions of external validity, i.e., generalization of the findings, may be problematic at this point in time. Second, the questioned individuals were only from two roadside assistance clubs, there are many more in Germany, whose members may have a different view and different issues when delivering their services to electric vehicles. Third, some relations to other upcoming technology trends such as autonomous cars have not been addressed in this study. These trends might interfere with each other, leading to an even higher service complexity in the future. Fourth, the focus of this study was put on the technological aspects of e-mobility. Even though legal and political aspects were not ignored, they are not in the center of our research, but may have an influence on the development of service complexity and service productivity of emobility.

We recommend that future research addresses these shortcomings. A wide-spread dissemination of the survey to other (European or global) contexts could validate the findings, discover respective market singularities and/or bring up new and more detailed insights into this important but neglected application of service research. We think that it should be seen as a starting point to initiate more research and to speed up the adaptation process of service firms to get them ready for the heavy acceleration of electric car penetration that has been on the political agenda for quite some time.

\section{Acknowledgement}

The research project "Szenariengestützte Entwicklung des Dienstleistungssystems "Sichere Versorgung bei Unfällen und Pannen mit Elektrofahrzeugen " (SafetE-car)" has been partially funded by a grant from the German Ministry for Education and Research (Bundesministeriums für Bildung und Forschung - BMBF) and has ben supervised by the project owner Karlsruhe (PTKA). The responsibility for the content of this publication lays with the authors. 


\section{References}

1. Radke, S.: Verkehr in Zahlen 2016/2017 [traffic in numbers 2016/2017]. DVV Media Group, Hamburg (2016)

2. SPIEGEL: Diesel-Pkw stoßen teils mehr Stickoxide aus als Lkw [diesel cars sometimes emit more nitric oxides than heavy trucks], http://www.spiegel.de/diesel-pkw-stossen-teils-mehr-stickoxide-1128839.html

3. Bundesregierung: Nationaler Entwicklungsplan Elektromobilität [national development plan electric mobility of the German government] (2009)

4. Smith, B.: Chevrolet volt battery incident overview report (2012)

5. Warner, J.: The handbook of lithium-ion battery pack design. Chemistry, components, types and terminology. Elsevier, Amsterdam (2015)

6. Chase, R.B., Haynes, R.M.: Service Operations Management: A Field Guide. In: Swartz, T.A., Iacobucci, D. (eds.) Handbook of services marketing \& management, pp. 455-472. Sage Publications, Thousand Oaks (2000)

7. Walsh, G., Walgenbach, P., Evanschitzky, H., Schaarschmidt, M.: Service Productivity: What Stops Service Firms from Measuring It? Journal of Organisational Transformation \& Social Change 13, 5-25 (2016)

8. Bullinger, H.-J., Scheer, A.-W., Schneider, K. (eds.): Service Engineering. Entwicklung und Gestaltung innovativer Dienstleistungen [Service Engineering: Development and design of innovative services]. Springer, Berlin (2006)

9. Ojasalo, K.: Conceptualizing productivity in services. Helsinki (1999)

10. Corsten, H., Gössinger, R.: Dienstleistungsmanagement [service management]. Oldenbourg Wissenschaftsverlag, München (2014)

11. Wacker, J., Hershauer, J., Walsh, K.D., Sheu, C.: Estimating professional service productivity. Theoretical model, empirical estimates and external validity. International Journal of Production Research 52, 482-495 (2013)

12. Grönroos, C., Ojasalo, K.: Service productivity. Towards a conceptualization of the transformation of inputs into economic results in services. Journal of Business Research 57, 414-423 (2004)

13. von Garrel, J., Tackenberg, S., Seidel, H., Grandt, C.: Dienstleistungen produktiv erbringen [productively delivering services]. Springer Gabler, Wiesbaden (2014)

14. Cocca, S.: Significance of Qualitative Factors for a Deeper Understanding of Service Productivity. International Journal of Service Science, Management, Engineering, and Technology 4, 46-59 (2013)

15. Denzin, N.K., Lincoln, Y.S.: The Sage handbook of qualitative research. Sage, Thousand Oaks, CA (2011)

16. Hair, J.F., Wolfinbarger, M., Money, A.H., Samouel, P., Page, M.J.: Essentials of business research methods. M.E. Sharpe, Armonk, N.Y. (2011)

17. Hair, J.F., Black, W.C., Babin, B.J., Anderson, R.E.: Multivariate data analysis. Prentice Hall, Upper Saddle River, NJ (2014)

18. Demmelmair, M.F.: Essays on service productivity: Theoretical foundation and selected empirical studies. FGM-Verlag, München (2015)

19. Calabrese, A.: Service productivity and service quality. A necessary trade-off? International Journal of Production Economics 135, 800-812 (2012). 